\title{
Pembelajaran Matematika Realistik Berbantuan Google Classroom untuk Meningkatkan Kemampuan Komunikasi dan Kemandirian Belajar Siswa
}

\author{
Netti Kariani Mendrofa \\ (Prodi Pendidikan Matematika, FPMIPA, IKIP Gunungsitoli, Sumatera Utara) \\ * Corresponding-Author. Email: netti.mend14@gmail.com
}

Receive: 13/02/2021

Accepted: 23/02/2021

Published: 01/03/2021

\begin{abstract}
Abstrak
Tujuan dan rumusan masalah dari penelitian ini adalah untuk mengetahui apakah dengan pembelajaran matematika realistik berbantuan google classroom dapat meningkatkan kemampuan komunikasi dan kemandirian siswa. Metode penelitian ini adalah penelitian deskriptif kuantitatif. Penelitian ini dilakukan di SMA Negeri 3 Gunungsitoli Tahun Pelajaran 2020/2021. Sampel dalam penelitian ini adalah kelas X MIPA-1 sebanyak 36 siswa yang di ambil dari jumlah populasi data dan dapat mewakili seluruh populasi dengan teknik pengumpulan sampel yaitu teknik random sampling. Instrumen yang digunakan adalah tes kemampuan komunikasi matematis dan angket dengan teknik analisis data yang dilakukan yaitu dengan menggunakan uji regresi berganda. Berdasarkan hasil dari penelitian ini menghasilkan nilai signifikan sebesar $0.001<0.05$ dan F hitung 5,366 $>$ F tabel 3,295. Dengan peningkatan kemampuan komunikasi dan kemandirian siswa secara simultan (bersamaan) terhadap variabel $\mathrm{Y}$ adalah sebesar 36\%. Sehingga dapat disimpulkan bahwa terdapat peningkatan kemampuan komunikasi dan kemandirian siswa melalui pembelajaran matematika realistik (PMR) berbantuan google classroom.
\end{abstract}

Kata kunci: Kemampuan komunikasi, kemandirian, matematika realistik

\begin{abstract}
The purpose and problem formulation of this research is to find out whether realistic mathematics learning assisted by google classroom can improve students' communication skills and independence. This research method is quantitative descriptive research. This research was conducted at SMA Negeri 3 Gunungsitoli for the academic year 2020/2021. The sample in this study was class X MIPA-1 as many as 36 students who were taken from the total population of data and could represent the entire population with a sample collection technique, namely random sampling technique. The instrument used is a test of mathematical communication skills and a questionnaire with data analysis techniques carried out by using multiple regression tests. Based on the results of this study resulted in a significant value of $0.001<0.05$ and $F$ count $5.366>F$ table 3.295. With the increase in students' communication skills and independence simultaneously (simultaneously) the $Y$ variable is $36 \%$. So it can be concluded that there is an increase in students' communication skills and independence through realistic mathematics learning (PMR) assisted by google classroom.
\end{abstract}

Keywords: Communication skills, independence, realistic mathematics

\section{Pendahuluan}

Pendidikan matematika merupakan salah satu cabang ilmu pengetahuan yang sangat penting dan bermanfaat dalam dunia pendidikan maupun dalam kehidupan sehari-hari. Dengan perkembangan zaman yang begitu pesat, pendidikan tidak lagi sulit untuk di mengerti dan dipelajari. Yang menjadi landasan penelitian ini dilakukan adalah rendahnya kemampuan komunikasi 
dan kemandirian siswa dalam menyelesaikan permasalahan matematika mengakibatkan antusias siswa dalam belajar sangat kurang (Sundayana, 2016; Ansori \& Sari, 2016).

Oleh karena itu perlu diadakan penelitian ini untuk meningkatkan kemampuan komunikasi dan kemandirian siswa. Dengan kondisi pandemi covid-19 seperti sekarang ini pembelajaran disekolah kurang kondusif dan peserta didik tidak fokus dalam belajar karena jam pelajaran yang sedikit di sekolah membuat peserta didik tidak mampu menangkap materi yang disampaikan oleh guru, dan mengakibatkan antusias siswa dalam belajar sangat kurang. Dan kurangnya inisiatif peserta didik untuk belajar secara mandiri di rumah agar dapat memahami pelajaran yang sudah disampaikan oleh guru disekolah. Apalagi pelajaran pendidikan matematika sedikit peminatnya dikarenakan dianggap sebagian besar para siswa merupakan salah satu mata pelajaran di sekolah yang sulit dipahami dan tidak disukai oleh para siswa. Padahal apabila kita dapat memahami konsep dari pembelajaran matematika tersebut dan fokus dalam belajar maka matematika tersebut bukanlah suatu hal yang harus ditakuti melainkan sesuatu yang dapat menumbuhkan semangat dalam belajar (Herawaty, 20018; Rohaety \& Purwarsih, 2018; Mendrofa, 2017). Maka perlu adanya pembelajaran matematika realistik (PMR) berbantuan google classroom untuk meningkatkan kemampuan komunikasi dan kemandirian siswa.

Kemampuan komunikasi sangat perlu untuk dikuasai oleh seorang peserta didik karena kemampuan komunikasi merupakan salah satu dari kompetensi pembelajaran matematika. Oleh karena itu setiap peserta didik harus memiliki kemampuan komunikasi yang baik agar mampu memahami dan menyelesaikan permasalahan pembelajaran yang sedang diajarkan. Apabila kemampuan komunikasi yang dimiliki oleh peserta didik kurang baik maka dapat menyebabkan tidak tercapainya peserta didik dalam menguasai atau memahami materi pembelajaran. Komunikasi secara umum adalah salah satu cara untuk menyampaikan suatu berita dari pembawa berita ke penerima berita untuk diberitahu, pendapat atau sikap baik langsung secara lisan ataupun tidak langsung melalui media.

Komunikasi merupakan suatu sarana untuk menyampaikan suatu pesan yang hendak disampaikan untuk tujuan tertentu. Dalam pembelajaran perlu adanya kemampuan komunikasi yang baik guna untuk menjelaskan atau menyampaikan suatu kejadian yang ada di sekolah atau di lingkungan sekitar. Permendiknas nomor 22 tahun 2006 mengungkapkan salah satu tujuan pembelajaran matemtika di jenjang pendidikan dasar dan menengah adalah mampu mengkomunikasikan gagasan dengan symbol tabel, diagram atau media lain untuk memperjelas keadaan atau masalah. Komunikasi adalah salah satu dari standar proses pembelajaran. Dimana dalam komunikasi hal ini tidak sekedar komunikasi secara lisan ataupun verbal tetapi juga komunikasi secara tertulis. Komunikasi merupakan salah satu standar proses pembelajaran dan komunikasi tidak hanya sekedar lisan tetapi juga secara tulisan. Dalam hal ini komunikasi dalam matematika mampu membantu guru untuk memahami kemampuan peserta didik dalam membangun dan menerapkan pemahamannya mengenai konsep dan proses matematika yang sedang dipelajari (Siregarm, dkk., 2018; Zaini \& Marsigit, 2014).

Seorang guru seharusnya mampu menciptakan lingkungan belajar yang menyenangkan dan memungkinkan peserta didik untuk secara aktif belajar dengan mengarahkan, menemukan dan mengembangkan pengetahuannya untuk dapat mencapai kemampuan komunikasi yang baik. Guru memiliki peran penting untuk memberikan inovasi dalam mengembangkan kemampuan komunikasi siswa untuk mengkomunikasikan hasil pembelajaran yang berkaitan dengan masalah matematika ke dalam bentuk 
gambar, grafik, maupun simbol-simbol yang dijadikan sebagai alat untuk menyelesaikan suatu permasalahan (Haji \& Abdullah, 2015; Veralita, 2018). Dan komunikasi adalah suatu tempat untuk peserta didik agar mampu berkomunikasi dengan teman, mendapatkan informasi, saling bertukar pikiran, saling berpendapat kepada orang lain, merumuskan konsep dan strategi dalam matematika terhadap penyelesaian dalam pencarian dan percobaan dalam matematika merupakan suatu modal dan sumber kekuatan untuk keberhasilan siswa.

Komunikasi matematis merupakan kemampuan siswa dalam: (1) menjabarkan suatu kejadian ke dalam bentuk bahasa, simbol, ide matematika; (2) menjabarkan ide, sutuasi, dan relasi matematika ke dalam bentuk bahasa biasa; (3) mendengarkan, bermusyawarah, dan menulis mengenai matematika; (4) memahami suatu penjabaran matematika; (5) menyampaikan kembali suatu masalah matematika dalam bahasa sendiri. Rendahnya pembelajaran matematika realistik (PMR) hal ini juga dapat disebabkan oleh komunikasi dan kemandirian siswa dalam belajar. Dalam dunia nyata pembelajaran matematika realistik (PMR) sangat dibutuhkan karena berhubungan dalam kehidupan sehari-hari. Agar mampu terwujudnya kemampuan komunikasi maka hendaknya pembelajaran matematika selalu ditujukan sehingga peserta didik dapat menguasai matematika dengan baik dan optimal (Afiani, 2017; Gusnarsi, dkk, 2017)..

Menurut KBBI (Kamus Besar Bahasa Indonesia), kata mandiri berarti mampu berdiri sendiri, sementara kemandirian adalah belajar mandiri untuk mencapai suatu tujuan agar mendapatkan prestasi yang baik. Pendidikan formal yang ada di sekolah diharapkan dapat menjadikan siswa yang mandiri, disiplin dan bertanggung jawab, dan peduli kepada kepentingan bangsa dan negara. Indikator kemampuan belajar siswa yaitu: (1) sikap tanjung jawab terhadap tugas; (2) kemampuan bagaimana cara belajar siswa; (3) untuk mengetahui strategi belajar siswa. Salah satu cara yang dapat dilakukan untuk oleh seorang guru untuk meningkatkan kemandirian siswa yaitu dengan cara memberikan pembelajaran yang disajikan dalam bentuk permasalahan yang ada di sekitar kehidupan sehari-hari. Dengan begitu setidaknya dapat membantu pola pikir siswa dalam menelaah soal yang diberikan.

Kemandirian siswa harus dikembangkan karena kemandirian belajar siswa adalah hal yang dapat menentukan keberhasilan belajar siswa. Dalam suatu kemandirian peserta didik mempunyai suatu sikap yang mampu dalam menyelesaikan pemecahan masalah untuk mencari sebab akibat dari berbagai pengetahuan yang diberikan dan mampu menarik kesimpulan dari cara penggunaan konsep dan metode. Kemandirian siswa merupakan suatu kegiatan yang berawal dari kemauan diri sendiri, belajar dengan mandiri dan tidak tergantung kepada orang lain, selain itu bertanggung jawab supaya tercapainya tujuan pembelajaraan yang diinginkan. Dengan mandirinya siswa dalam belajar diharapkan mampu menyelesaikan suatu permasalan yang di dapat, dapat menggali informasi dari berbagai sumber lain selain dari guru dan lingkungan sekolah, serta dapat menumbuhkan sikap postif, rasa percaya diri, dan dapat memperbaiki diri. Dapat dikatakan pembelajaran matematika realistik ialah suatu pembelajaran dimana perpaduan antara teori dan kenyataan harus seimbang sehingga dapat di aplikasikan kehidupan sehari-hari. Pendekatan pembelajaran matematika realistik merupakan suatu pendekatan belajar matematika dengan memberikan kesempatan kepada siswa untuk menemukan konsep pembelajaran matematika melalui pemecahan terhadap masalah realistik. Pembelajaran matematika realistik memberikan peluang kepada siswa agar menemukan kembali dan menjelaskan konsep-konsep matematika berdasarkan pada masalah realistic yang diberikan oleh guru. Pembelajaran matematika realistik 
merupakan kegiatan manusia yang dikembangkan dengan prinsip dasar yaitu (1) guided reinvention and progressive mathematization (penemuan terbimbing dan bermatematika secara progresif); didactial phenomenology (penomena dalam pembelajaran); (3) self-developed models (pengembangan model secara mandiri). Kegiatan belajar mengajar perlu memperhatikan karakteristik pembelajaran matematika realistik yaitu: menggunakan masalah kontekstual; (2) menggunakan model atau jembatan sebagai instrumen vertikal; (3) menggunakan konstribusi siswa; (4) interaktifitas; (5) terintegrasi dengan topik pembelajaran lainnya. Pendidikan pembelajaran matematika realistik inilah yang bisa menjadi solusi untuk mengatasi kemampuan komunikasi dan kemandirian siswa. Adapun tahap pembelajaran matematika realistik yang dilakukan agar pelaksanaanya dapat berjalan dengan baik dan benar.

Dalam menuntut ilmu banyak cara yang dilakukan salah satunya menggunakan internet. Ada saat ini banyak sekali informasi-informasi yang dapat kita lihat ataupun temukan dalam internet mau dalam dunia pendidikan, bisnis maupun yang lainnya. Dengan keadaan yang seperti ini pembelajaran secara daring/online sangat dibutuhkan oleh seorang guru untuk agar pembelajaran dapat terus berjalan dengan baik. Dalam bidang pendidikan, internet sangat membantu dalam pembelajaran saat ini yaitu secara daring atau online dikarenakan pada saat ini diharuskan belajar dari rumah akibat dari pandemic covid-19 yang belum redam saat ini juga. Dan salah satu solusinya untuk belajar dari rumah dapat terlaksana dan berjalan menerus yang dilakukan oleh seorang guru di sekolah yaitu dengan menggunakan aplikasi google classroom yang ada di google. Dengan adanya google classroom saat ini diharapkan dapat membentuk para guru dalam mengajar atau memberikan soal kepada siswanya (Nurani, dkk., 2020).
Google classroom juga mampu membuat salinan otomatis dari tugas yang sudah diberikan oleh guru dan mampu memeriksa dan menilai tugas yang diberikan secara otomatis. Manfaat dari google classroom yaitu: (1) mudah disiapkan; (2) menghemat waktu; (3) meningkatkan pengelompokan; meningkatkan komunikasi; (5) dana yang terjangkau. Google classroom adalah salah satu teknologi yang dibuat oleh google untuk mempermudah murid dan guru pada proses pembelajaran di dalam ataupun di luar kelas untuk merancang, mengembangkan, dan menggolongkan setiap penugasan tanpa adanya kertas. Penggunaan google clasroom juga tergolong mudah, dapat di akses melalui aplikasi melalui playstore yang ada pada android ataupun website yang terdapat di google chrome (Ghofur, 2018).

\section{Metode}

Metode penelitian ini adalah penelitian deskriptif kuantitatif. Dengan pengambilan sampel ialah menggunakan teknik simple random sampling. Dalam penelitian ini terdapat 3 variabel, yakni dua variabel independen (bebas) yaitu $\mathrm{X}_{1}$ (komunikasi matematis) dan $\mathrm{X}_{2}$ (kemandirian). serta satu variabel dependen (terikat) yaitu Y (pembelajaran matematika realistik). Hubungan antara variabel tersebut dapat dilihat pada gambar berikut.

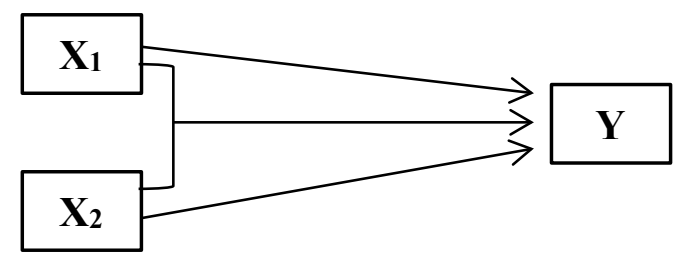

Gambar 1. Hubungan antar variable

$\mathrm{X}_{1}=$ kemampuan komunikasi siswa

$\mathrm{X}_{2}=$ kemandirian siswa

$\mathrm{Y}=$ pembelajaran matematika realistik

Untuk mencari hubungan X1dengan $\mathrm{Y}$, dan $\mathrm{X} 2$ dengan $\mathrm{Y}$ menggunakan teknik analisis data uji regresi berganda. Untuk mencari hubungan $\mathrm{X}_{1}$ dengan $\mathrm{X}_{2}$ secara simultan (bersamaan) terhadap $\mathrm{Y}$ 
menggunakan teknik analisis data uji korelasi berganda. Populasi pada penelitian ini yaitu Kelas X SMA Negeri 3 Gunungsitoli. Dan sampel pada penelitian ini adalah siswa kelas X MIPA-1 sebanyak 36 siswa, dengan teknik pengambilan sampel menggunakan teknik simple random sampling. Teknik pengumpulan data menggunakan tes essay dan angket. Dimana tes essay yang terdiri dari 5 soal digunakan untuk mengukur kemampuan komunikasi siswa. Dan angket digunakan untuk mengukur kemampuan kemandirian siswa. Teknik analisis data penelitian ini adalah statistik deskriptif menggunakan uji regresi berganda. Penelitian ini bertujuan untuk mengetahui seberapa besar peningkatan kemampuan komunikasi dan kemandirian siswa melalui pembelajaran matematika realistik berbantuan google classroom.

\section{Hasil dan Pembahasan}

Penelitian ini dilakukuan untuk membuktikan apakah ada peningkatan antara variabel bebas $\mathrm{X}_{1}$ (komunikasi) dan $\mathrm{X}_{2}$ (kemandirian) dengan variabel terikat $\mathrm{Y}$ (pembelajaran matematika realistik) yang dilakukan dengan menggunakan teknik analisis data uji regresi berganda. Hasil perhitungan dapat dilihat pada tabel 1 untuk hasil uji t.

Tabel 1. Hasil Uji t

\begin{tabular}{|c|c|c|c|c|c|c|}
\hline Var be & tater & Sampel & Sig & thintr & tibolal & \\
\hline \multirow{2}{*}{$\frac{\text { Komumikasi }(X)}{\text { Kemandirian }}$} & \multirow{2}{*}{$P \operatorname{PMR}(Y)$} & 36 & 0,003 & 3,354 & \multirow{2}{*}{1,6} & $\mathrm{n}_{0} 0$ \\
\hline & & 36 & 0,627 & 0,489 & & \\
\hline
\end{tabular}

Dari tabel 1 diketahui nilai signifikan untuk peningkatan kemampuan komunikasi (X1) terhadap pembelajaran matematika realistik (Y) adalah sebesar $0.003<0.05$, dan nilai thitung $3.354>t_{\text {tabel }}$ 1.6909.Sehingga dapat disimpulkan bahwa H0 ditolak, maka terdapat peningkatan kemampuan komunikasi $\left(\mathrm{X}_{1}\right)$ terhadap pembelajaran matematika realistik (Y). Dan juga diketahui nilai signifikan untuk peningkatan kemandirian siswa $\left(\mathrm{X}_{2}\right)$ terhadap pembelajaran matematika realistik (Y) adalah sebesar $0.627>0.05$, dan nilai thitung $0.489<\mathrm{t}_{\text {tabel }}$ 1.6909. Sehingga dapat disimpulkan bahwa $\mathrm{H}_{0}$ diterima, maka tidak terdapat peningkatan kemandirian siswa $\left(\mathrm{X}_{2}\right)$ terhadap pembelajaran matematika realistik $(\mathrm{Y})$.

Tabel 2. Hasil Uji F

\begin{tabular}{|c|c|c|c|c|c|c|}
\hline Varbebas & Vay terlikat & Sampel & $\mathrm{Sig}$ & Fiturge & $F_{\text {tabol }}$ & Kesimpulan \\
\hline $\begin{array}{l}\text { Komunikasi }\left(X_{1}\right) \\
\text { Kemanditian (X. }\end{array}$ & $\operatorname{PMR}(1)$ & 36 & 0,001 & 5,366 & 3,295 & dak \\
\hline
\end{tabular}

Berdasarkan tabel 2 diketahui nilai signifikan untuk peningkatan kemampuan komunikasi $\left(\mathrm{X}_{1}\right)$ dan kemandirian $\left(\mathrm{X}_{2}\right)$ secara simultan terhadap pembelajaran matematika realistik (Y) adalah sebesar $0.010<0.05$ dan nilai $\mathrm{F}$ hitung $5.663>\mathrm{F}$ tabel 3.42. Sehingga dapat disimpulkan bahwa $\mathrm{H}_{0}$ ditolak, maka terdapat peningkatan kemampuan komunikasi dan kemandirian siswa melalui pembelajaran matematika realistik (PMR) berbantuan google classroom.

Tabel 3. Hasil Uji Koefisien Determinasi

\begin{tabular}{|c|c|c|c|}
\hline Var bebas & Var terikat & $\begin{array}{c}\text { Koef Determinasi } \\
\text { (R Square) }\end{array}$ & Kesimpulan \\
\hline $\begin{array}{l}\text { Komunikasi }\left(\mathrm{X}_{1}\right) \\
\text { Kemandirian }\left(\mathrm{X}_{2}\right)\end{array}$ & PMR $(\mathrm{Y})$ & 0.360 & $36 \%$ \\
\hline
\end{tabular}

Berdasarkan tabel 3 diketahui nilai $\mathrm{R}$ square sebesar 0.340 , hal ini mengandung arti bahwa peningkatan variabel $\mathrm{X}_{1}$ (komunikasi) dan variabel $\mathrm{X}_{2}$ (kemandirian) secara simultan (bersamaan) terhadap variabel $\mathrm{Y}$ (pembelajaran matematika realistik) adalah sebesar $36 \%$. Berdasarkan hasil analisis data dengan menggunakan uji analisis regresi berganda diperoleh uji $t$, uji $F$ dan koefisien determinasi. Terdapat beberapa hasil penelitian terdahulu yang sesuai dengan penelitian yang telah dilakukan oleh peneliti. Berdasarkan penelitian yang dilakukan Soni (2018) bahwa pembelajaran menggunakan pendekatan Realistic Matematics Education (RME) dapat meningkatkan kemampuan komunikasi matematis siswa menjadi lebih baik dibandingkan dengan siswa yang 
mendapatkan pembelajaran secara biasa. Dan siswa memiliki kemandirian belajar yang cenderung positif dengan mendapatkan pembelajaran menggunakan pendekatan Realistic Matematics Education (RME).

Berdasarkan penelitian Ghofur (2018) bahwa tujuan penelitian ini yaitu untuk mengetahui peningkatan kemampuan komunikasi matematika siswa menggunakan Pembelajaran Matematika Realistik (PMR) dengan siswa yang menggunakan pembelajaran biasa. Berdasarkan hasil penelitian yang dilakukan menunjukkan bahwa dengan Pembelajaran Matematika Realistik (PMR) pencapaian ketuntasan hasil kemampuan komunikasi matematika siswa lebih besar dibandingkan dengan kelas yang menggunakan pembelajaran konvensional. Dengan hasil penelitian ini menunjukkan bahwa pembelajaran matematika realistik (PMR) berbantuan google classroom terbukti dapat memberikan efek yang baik dalam meningkatkan kemampuan komunikasi dan kemandirian siswa secara bersama-sama. Terbukti dengan hasil analisis data yang telah dijelaskan diatas bahwa terjadi peningkatan kemampuan komunikasi dan kemandirian siswa terhadap pembelajaran matematika realistik (PMR) dari hasil uji $\mathrm{F}$, dimana nilai $\mathrm{F}_{\text {hitung }}$ (5.366) $>\quad F_{\text {tabel }}$ (3.295) sehingga dapat dikatakan H0 ditolak. Dengan demikian peneliti dapat menyimpulkan bahwa pembelajaran matematika realistik (PMR) berbantuan google classroom dapat membantu meningkatkan kemampuan komunikasi dan kemandirian siswa.

\section{Simpulan}

Berdasarkan hasil dan pembahasan penelitian ini dapat disimpulkan bahwa terdapat peningkatan kemampuan komunikasi $\left(\mathrm{X}_{1}\right)$ dan kemandirian siswa $\left(\mathrm{X}_{2}\right)$ melalui pembelajaran matematika realistic (Y) berbantuan google classroom yang dapat dilihat hasilnya ialah nilai $F$ hitung $5.366>\mathrm{F}$ tabel 3.295. Dengan demikian dsimpulkan bahwa pembelajaran matematika realistik (PMR) berbantuan google classroom dapat membantu meningkatkan kemampuan komunikasi dan kemandirian siswa.

\section{Daftar Pustaka}

[1] Sundayana, R. (2016). Kaitan antara gaya belajar, kemandirian belajar, dan kemampuan pemecahan masalah siswa SMP dalam pelajaran matematika. Mosharafa: Jurnal Pendidikan Matematika, 5(2), 75-84.

[2] Ghofur, A. (2018). Using Google Classroom On Inquiry Based Learning To Improves Students' Learning Participation. Jurnal Penelitian Pendidikan, 10(2), 1503-1509.

[3] Ansori, H \& Sari, E.M, (2016). Meningkatkan Kemampuan Komunikasi Matematis Siswa Melalui Model Pembelajaran Contextual Teaching and Learning kelas VIII SMP. EDU-MAT Jurnal Pendidikan Matematika, .4(1), 32-39.

[4] Afiani, N. (2017). Pengaruh Kemampuan Komunikasi Matematis dan Kemandirian Belajar terhadap Prestasi Belajar Matematika. JKPM (Jurnal Kajian Pendidikan Matematika), 2(1), 1-13.

[5] Gusnarsi, D., Utami, C., \& Wahyuni, R. (2017). Pengaruh Model Pembelajaran Realistic Mathematics Education (RME) Terhadap Kemampuan Penalaran Matematis Siswa Pada Materi Lingkaran Kelas VIII. JPMI (Jurnal Pendidikan Matematika Indonesia), 2(1), 32-36.

[6] Haji, S., \& Abdullah, M. I. (2015). Membangun kemandirian belajar siswa melalui pembelajaran matematika realistik. Infinity Journal, 4(1), 39-46.

[7] Herawaty, D. (2018). Model pembelajaran matematika realistik yang efektif untuk meningkatkan kemampuan matematika siswa SMP. 
Jurnal Pendidikan Matematika Raflesia, 3(2), 107-126.

[8] Veralita, L. (2018). Meningkatkan Kemampuan Komunikasi Matematik dan Kemandirian Belajar Siswa SMP melalui Pendekatan Realistic Mathematics Education. AKSIOMA : Jurnal Matematika dan Pendidikan Matematika, 113.

[9] Rohaeti, E. E., \& Purwasih, R. (2018). Meningkatkan Komunikasi Matematik Kemampuan Kemandirian Belajar Siswa SMP melalui Pendekatan Realistic Mathematics Education. AKSIOMA: Jurnal Matematika dan Pendidikan Matematika, 9(1), 113-123.

[10] Siregar, A. S., Surya, E., Syahputra, E., \& Sirait, A. R. (2018). The Improving Mathematical Communication Ability and Students' Self-Regulation Learning through Realistic Mathematical Approach Based on Batak Toba Culture. American Journal of Educational Research, 6(10), 13971402.

[11] Zaini, A., \& Marsigit, M. (2014). Perbandingan keefektifan pembelajaran matematika dengan pendekatan matematika realistik dan konvensional ditinjau dari kemampuan penalaran dan komunikasi matematik siswa. Jurnal
Riset Pendidikan Matematika, 1(2), 152-163.

[12] Nurani, N. I., Uswatun, D. A., \& Maula, L. H. (2020). Analisis Proses Pembelajaran Matematika Berbasis Daring Menggunakan Aplikasi Google Classroom Pada Masa Pandemi Covid19. Jurnal PGSD, 6(1), 50-56.

[13] Mendrofa, N. K. (2017). Pengembangan Alur Pembelajaran Perbandingan Berbasis Realistic Mathematics Educationuntuk Siswa Kelas VII SMP. Lemma, 3(2), 24601047

[14] Soni. (2018). Optimalisasi Pemanfaatan Google classroom Sebagai Media Pembelajaran Di SMK Negeri 1 Bangkinang. Jurnal Pengabdian Untuk Mu Negeri, 2(1), 17-20.

\section{Profil Penulis}

Netti Kariani Mendrofa, S.Pd., M.Pd. adalah dosen tetap di Yayasan Perguruan Tinggi Nias. Beliau mengajar di FPMIPA Prodi Pendidikan Matematika, IKIP Gunungsitoli. Penulis Lulus S1 pada tahun 2012 di Prodi Pendidikan Matematika IKIP Gunungsitoli dan Lulus S2 pada tahun 2017 di Prodi Pendidikan Matematika Universitas Negeri Padang (UNP). 